\title{
Corporeidade e prática docente na Educação do Campo na Amazônia paraense
}

\author{
RODRIGUES, Rosenilma Branco (Brasil, Pará, Santarém) ${ }^{1 *}$ \\ COUTO, Hergos Ritor Fróes de (Brasil, Pará, Santarém) ${ }^{1^{\star \star}}$ \\ ${ }^{1}$ Universidade Federal do Oeste do Pará \\ ORCID ID: https://orcid.org/0000-0003-2058-4341* \\ ORCID ID: https://orcid.org/0000-0002-0101-4012*
}

\begin{abstract}
Resumo
Este trabalho teve como objetivo investigar, a partir dos fundamentos da Corporeidade e Educação do Campo, os sentidos que os professores atribuem ao corpo na prática docente nos territórios rurais de Santarém, localizado na Amazônia paraense. Metodologicamente é um estudo qualitativo com abordagem fenomenológica, organizado em duas etapas: pesquisa bibliográfica e de campo. Para a produção e análise dos dados, utilizou-se da técnica de elaboração e análise de unidades de significado, desenvolvida por Moreira, Simões e Porto (2005). Os desdobramentos teóricos imputam um diálogo entre Corporeidade e Educação do Campo, sustentando-se em autores que evocam sobre as temáticas. Os dados de campo centraram-se no discurso dos sujeitos, por meio dos quais se constatou que eles compreendem o corpo em sua totalidade, com múltiplas possibilidades de saberes e interação social, bem como verificou-se que há vivências de Corporeidade na prática docente com valorização dos saberes camponeses.
\end{abstract}

\section{Palavras-chave}

Amazônia. Educação do Campo. Vivências de Corporeidade.

\section{Corporeity and teacher practice in the education of the field in the Paraense Amazon}

\begin{abstract}
The objective of this study was to investigate, from the foundations of Corporeity and Field Education, the meanings that teachers attribute to the body in teaching practice in the rural territories of Santarém, located in the Amazon Paraense. Methodologically, it is a qualitative study with a phenomenological approach, organized in two stages: bibliographical and field research. For the production and analysis of data, we used the Technique of Elaboration and Analysis of Units of Significance, developed by Moreira, Simões and Porto (2005). Theoretical developments impute a dialogue between Corporeity and Field Education, supported by authors who evoke the themes. Field data focused on subjects' discourse, through which it was found that they comprehend the body in its totality, with multiple possibilities of knowledge and social interaction. As well, it has been verified that there are experiences of corporeity in the teaching practice with valorization of the peasant knowledge.
\end{abstract}

\section{Keywords}

Amazon. Field Education. Corporeity experiences. 


\title{
Corporeidad y práctica docente en la Educación del Campo en la Amazonia paraense
}

\begin{abstract}
Resumen
Este trabajo tuvo como objetivo investigar, a partir de los fundamentos de la Corporeidad y Educación del Campo, los sentidos que los profesores atribuyen al cuerpo en la práctica docente en los territorios rurales de Santarém, en la Amazonia paraense. Metodológicamente es un estudio cualitativo con enfoque fenomenológico, organizado en dos etapas: investigación bibliográfica y de campo. Para la producción y análisis de los datos, se utilizó de la técnica de elaboración y análisis de unidades de significado, desarrollada por Moreira, Simões y Oporto (2005). Los desdoblamientos teóricos imputan un diálogo entre Corporeidad y Educación del Campo, sosteniéndose en autores que evocan sobre las temáticas. Los datos de campo se centraron en el discurso de los sujetos, a través de los cuales se constató que ellos comprenden el cuerpo en su totalidad, con múltiples posibilidades de saberes e interacción social, así como se verificó que hay vivencias de Corporeidad en la práctica docente con valorización de los saberes campesinos.
\end{abstract}

Palabras clave

Amazonas. Educación del Campo. Vivencias de Corporeidad.

\section{INTRODUÇÃO}

O corpo é um tema constante, instigante e que provocou e ainda provoca concordâncias e discordâncias a respeito das diferentes concepções a seu respeito desenvolvidas no decorrer da história da humanidade. As sociedades vivem de acordo com cada espaço-tempo, o que proporciona uma dinâmica social que possibilitou a ideia de corpo estruturado conforme a própria produção cultural de cada época, gerando sentidos e significados variados.

Na cultura ocidental, em especial, no pensamento de Platão, percebe-se o corpo voltado para a ginástica como forma de educação para os cidadãos. Na Idade Média, Santo Agostinho retoma as ideias platônicas que dividiam o ser humano em corpo e alma, contudo acresce mais um elemento que animaria a alma, a divindade - Deus. Em Rousseau, tem-se as considerações sobre a educação do Emílio, um romance pedagógico que traz críticas sobre a educação tradicional, que, ao primar pelo progresso, faz com que as crianças sejam instigadas ao desenvolvimento do intelecto, deixando esquecidas a educação física e outras dimensões humanas, como a formação do caráter moral (NÓBREGA, 2010). 
Com efeito, a Idade Moderna é um marco importante na produção do conhecimento, quando surgem as teorias que vão questionar a capacidade humana de conhecer, levando ao surgimento das questões epistemológicas que deram ênfase a essa questão: o racionalismo (enfatiza o aprendizado por meio da razão) e o empirismo (enfatiza o aprendizado mediante as experiências), ambas as correntes por muito tempo caminharam separadamente, afirmando-se como teoria do conhecimento. O racionalismo, antes mesmo das ideias iluministas rousseaunianas, foi a primeira corrente filosófica referente à teoria do conhecimento, seu principalmente representante foi René Descartes.

Descartes, criador do método cartesiano, buscou desenvolver um método seguro e universal que conduzisse à verdade inquestionável. Com isso, baseou-se no conhecimento puramente racional. Ao dividir o ser humano em corpo e mente, atribuiu a esta última a faculdade da inteligência, do conhecimento, negando a capacidade dos sentidos como meio para o aprendizado. Nessa conjuntura, ficou sob domínio dos empiristas, em especial, de David Hume, a defesa de que o conhecimento dar-se-á pela percepção. O empirista John Locke, contrapondo-se ao ideal racionalista, critica a doutrina de ideias inatas de Descartes e compara a alma com uma tábula rasa, sem conhecimentos, pois serão produzidos e reproduzidos por meio das experiências sensíveis.

O racionalismo vai incutir a limitação das experiências corporais no processo de formação do conhecimento. Essa ideia é disseminada nas instituições de ensino, levando ao tradicionalismo, à educação mecânica, ao disciplinamento e à concepção do corpo-objeto, aquele que é manipulado e docilizado, "[...] é dócil um corpo que pode ser submetido, que pode ser utilizado, que pode ser transformado e aperfeiçoado" (FOUCAULT, 2014, p. 134).

As corroborações foucaultianas constatam que modelos provenientes do sistema capitalista influenciaram fortemente o funcionamento das escolas, a exemplo das regras que eram implementadas nas fábricas. Esse modelo fabril foi transportado para a escola, - que a tornou uma referência como reguladora e opressora das manifestações corporais de seus alunos, legitimando o disciplinamento e a docilização como controle e organização escolar. Por outro lado, a escola pode ser, ao mesmo tempo, transcendente das experiências educacionais por meio de vivências corporais. Frisa-se que 0 racionalismo, apesar de elevar a desqualificação do corpo, foi o eixo condutor para problematizá-lo como objetivo de pesquisa que começa a ocorrer somente no século XX. 
No contexto dos territórios rurais, a ideia de corpo-objeto foi facilmente verificável, pois o modelo de "Educação Rural" que vigorava não tencionava 0 desenvolvimento do sujeito camponês, mas os interesses capitalistas na exploração da mão de obra. Eram pessoas tratadas como se seus corpos fossem objetos, desprovidos de anseios, dores e lamentos, serviam como instrumento para a produção de alimentos que abasteciam os grandes centros urbanos. A desumanização que configurava a "Educação Rural" implica a ideia de um corpo-objeto, como denunciava Foucault (2014) sobre os corpos oprimidos, docilizados, corpos domesticados para atender às demandas dos opressores. "Nessa perspectiva, o corpo é visto como objeto a ser disciplinado, visando ao aprimoramento físico e moral das pessoas, a eficiência e a produtividade da sociedade industrial" (NÓBREGA, 2005, p. 45).

A transição da Educação Rural para a Educação do Campo é demarcada pela organização e mobilização social em defesa de uma educação voltada para os interesses e necessidades daqueles que vivem do e no campo.

Em confronto com a educação rural negada, a educação do campo construída pelos movimentos populares de luta pela terra organizados no movimento camponês articula o trabalho produtivo à educação escolar tendo por base a cooperação. A educação do campo não admite a interferência de modelos externos, e está inserida em um projeto popular de sociedade, inspirado e sustentado na solidariedade e na dignidade camponesa. (RIBEIRO, 2012, p. 300).

Portanto, advogar a respeito da corporeidade na educação, em particular, na Educação do Campo, parte da preocupação e necessidade em olhar o processo de ensino-aprendizagem como um mecanismo de desenvolvimento social, emancipador, democrático e humano (COUTO, 2008; GONÇALVES, 2012; MOREIRA, 2014; NÓBREGA, 2005, 2010). Nesse sentido, compreende-se que o corpo é a condição de existência humana e participa de uma construção social e histórica, por meio dele traçamos aspirações da nossa subjetividade e interagimos com outrem e com o mundo (MOREIRA, 2014). A Corporeidade no processo educacional enfatiza que:

[...] a necessidade dessa nova atitude pedagógica, não nos preocupando com as críticas ou negações ao já estabelecido. Buscar a presença da corporeidade na escola é superar os padrões atuais existentes do entendimento e do trabalho com o corpo do aluno no ambiente escolar, escrevendo e vivenciando uma nova história, ao mesmo tempo em que

Educação \& Formação, Fortaleza, v. 5, n. 13, p. 113-131, jan./abr. 2020

DOI: https://doi.org/10.25053/redufor.v5i13.1439

http://seer.uece.br/redufor 
temos consciência de estarmos sendo modificados por esta história dialógica. (MOREIRA, 2014, p. 152).

A Corporeidade se dará como possibilidade de reflexão a respeito dos padrões educacionais estabelecidos que negam o corpo como meio de aprendizado e é justamente por ele que o indivíduo se desenvolve, pois, se educação, como viés de mudança e formação do ser humano, reduz ou nega a importância do corpo na constituição do conhecimento, deixa de fazer o seu papel social, democrático e crítico.

Sob essa perspectiva, considerando a importância da corporeidade na formação educacional, em especial na escolar, e nas mudanças de paradigmas, buscou-se investigar, a partir dos fundamentos da Corporeidade e da Educação do Campo, os sentidos que os professores atribuem ao corpo na prática docente nos territórios rurais de Santarém, localizado na Amazônia paraense. Os sentidos arrolados no objetivo serão identificados nas falas das professoras que trabalham nos territórios rurais.

\section{PERCURSO METODOLÓGICO}

O estudo foi realizado no município de Santarém, na Amazônia paraense. De acordo com o Censo de 2017 elaborado pela Secretaria de Educação de Santarém, a maioria das escolas (equivalente a mais de 200 instituições) está localizada nos territórios rurais. Cabe ressaltar algumas dificuldades percebidas, entre elas: algumas turmas são multisseriadas, dificuldade de acesso às escolas e falta de estruturas físicas e pedagógicas. Por outro lado, possuem uma diversidade sociocultural abundante. Salienta-se que a Secretaria de Educação de Santarém, para efeitos de gestão educacional, dividiu as localizações das escolas em áreas urbanas, planalto (concentra as escolas em que o acesso se dá por via terrestre) e rios (em que o meio de acesso ocorre via fluvial). Nas escolas ribeirinhas e planalto, estão presentes também as escolas indígenas e quilombolas.

O estudo apresentado foi realizado em uma escola ribeirinha localizada na Vila Lago Grande do Curuai, onde a cheia e a vazante do rio determinam a vida das pessoas que ali residem. O rio é um dos caminhos que levam as crianças às escolas, sendo as embarcações o meio de transporte, quando por via terrestre geralmente vão caminhando ou de bicicleta; os educandos, em sua maioria, são da própria comunidade, mas há 
outros de locais mais distantes. Destaca-se que os meios de produção econômica da localidade são a agricultura e a pesca.

Os critérios de escolha do lócus da pesquisa foram: ser uma escola do território rural, ribeirinha, que obtivesse maior concentração de alunos, estivesse localizada no Lago Grande do Curuai (local de referência pessoal dos pesquisadores), obter professores do ensino fundamental menor $-1^{\circ}$ ao $5^{\circ}$ ano.

$\mathrm{Na}$ escola havia oito professoras nesse nível de ensino, assim abarcou-se a totalidade dos sujeitos de acordo com os critérios estabelecidos. Foram seguidos os aspectos éticos da pesquisa científica com assinatura dos Termos de Consentimento Livre e Esclarecido (TCLE), mantendo o sigilo da identidade de batismo ou cartório. Foi solicitado a cada professora escolher o nome com o qual desejariam ser identificadas na pesquisa. Conforme descrição dos Quadros 1 e 2, os nomes definidos foram: Tânia, Pajurá, Mary, Bem-te-vi, Helen, Eva das Rosas, Violeta e Maria. Elas possuíam em média de 15 a 33 anos de tempo de serviço, a maioria em condição estável, com exceção da professora Pajurá, que estava havia dois meses no exercício da docência, pois havia seis meses que cursava sua primeira graduação, em Pedagogia. Antes de estar como docente, exercia função operacional na escola. Das professoras pesquisadas, apenas uma havia exercido a prática docente em escolas da zona urbana, as outras com experiência oriunda do espaço campesino.

Considerou-se este estudo de natureza qualitativa, com abordagem fenomenológica. A pesquisa qualitativa permite a aproximação do pesquisador com 0 objeto pesquisado, além de poder adentrar no universo dos significados das relações humanas. Para Minayo (1994, p. 21), a pesquisa qualitativa se preocupa:

[...] com um nível de realidade que não pode ser quantificado. Ou seja, ela trabalha com o universo de significados, motivos, aspirações, crenças, valores e atitudes, o que corresponde a um espaço mais profundo das relações, dos processos e dos fenômenos que não podem ser reduzidos à operacionalidade de variáveis.

A abordagem fenomenológica se dá pela intencionalidade do pesquisador com o objeto de estudo, considerando o contexto social dos sujeitos da pesquisa que foram elementos importantes para a interpretação dos dados. Entende-se que a fala das professoras, objeto principal de análise, é carregada de sentidos, significados e valores. Para Siani, Correa, Casas (2016, p. 193): 
A abordagem fenomenológica, enquanto roteiro de procedimentos desdobra-se em duas grandes vertentes: a filosófica e a empírica. Em ambas as vertentes o ponto de partida é a realidade social dos sujeitos e o objetivo é a sua compreensão. No âmbito filosófico, essa compreensão estará sempre centrada naquele que conduz a análise de um fenômeno até o alcance da sua essência. No âmbito empírico, o objeto de análise é sempre uma parcela do mundo que é do outro. A apreensão desta parcela pelo pesquisador leva, forçosamente, a obtenção de relatos sobre a experiência vivida do outro para alcançar o fenômeno, ou seja, a 'coisa em si mesma'.

No contexto da experiência vivida das professoras, considerou-se que a escola pesquisada possui adversidades que interferem na prática docente, como: as longas distâncias percorridas por alunos, a insuficiência de estrutura financeira das famílias e a ausência da própria família como corresponsável pela formação da criança. Sobre a professora com pouca experiência em sala de aula, suas dificuldades são justificadas pela ainda incompleta formação acadêmica e inexperiência docente. Todos esses fatores, ainda que não sejam o foco analítico da pesquisa, estão atrelados ao processo de ensino-aprendizagem e, portanto, às falas das professoras.

Cabe lembrar que outro fator que justifica a opção pela abordagem fenomenológica consiste na própria escolha do instrumento de produção e análise dos dados, a técnica de elaboração e análise de unidades de significado, desenvolvida por Moreira, Simões e Porto (2005). Ressalta-se que, de acordo com os autores, "[...] a estrutura teórico/epistemológica da proposta está vinculada aos pressupostos fenomenológicos, em especial na obra de Merleau-Ponty quando do trato com o fenômeno corporeidade" (MOREIRA; SIMÕES; PORTO, 2005, p. 107). Essa técnica consiste em três momentos: relato ingênuo, identificação de atitudes e interpretação.

O primeiro momento se deu pela entrevista semiestruturada, com duas perguntas geradoras: "O que é corpo para você?"; "Que sentidos você atribui ao corpo na sua prática docente?". O segundo momento referiu-se à seleção das unidades de significados a partir dos relatos que foram organizados conforme os Quadros 1 e 2. 0 terceiro momento ocorreu no ato da análise das unidades de significado, em que o referencial teórico ajudou na sustentação e/ou confrontação de ideias. A técnica prevê que a segunda pergunta somente se realize após a resposta da primeira, evitando, assim, interferências para a resposta posterior. É válido salientar que a pesquisa deu-se pelo levantamento bibliográfico e pesquisa de campo. 


\section{CORPOREIDADE E EDUCAÇÃO DO CAMPO NA AMAZÔNIA: O QUE DIZEM OS SUJEITOS}

Iniciada a entrevista, a primeira pergunta realizada foi "O que é corpo para você?". Antes das respostas, todos os sujeitos solicitaram tempo para refletir sobre a questão, pois, segundo as professoras, era uma indagação até então impensada. A partir das falas, os dados extraídos foram interpretados abaixo:

Quadro 1 - Unidade de significado referente à questão: "O que é corpo para você?"

\begin{tabular}{|c|c|c|c|c|c|c|c|c|c|}
\hline Sujeitos & & & & & & & & & \\
\hline Unidades de significado & 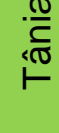 & $\frac{\sqrt{2}}{\bar{\sigma}}$ & $\stackrel{\frac{\pi}{\pi}}{\sum}$ & $\begin{array}{l}\frac{0}{1} \\
\frac{1}{0} \\
\infty\end{array}$ & $\frac{\overline{0}}{\frac{0}{I}}$ & 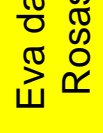 & $\frac{+0}{\circ}$ & $\frac{\sqrt[0]{\frac{\pi}{\pi}}}{\sum}$ & $\underset{+\frac{\pi}{0}}{\stackrel{\overline{0}}{\circ}}$ \\
\hline O corpo é tudo em nossa vida. & $\mathrm{X}$ & & $X$ & & $\mathrm{X}$ & $\mathrm{X}$ & & & 4 \\
\hline Uma máquina. & & & $X$ & & & & & & 1 \\
\hline $\begin{array}{l}\text { Corpo é tudo aquilo que tem massa e } \\
\text { ocupa um lugar no espaço físico. }\end{array}$ & & & & $X$ & & & & & 1 \\
\hline Ele está presente em todos os momentos. & $\mathrm{X}$ & & & $\mathrm{X}$ & $x$ & $\mathrm{X}$ & & $X$ & 5 \\
\hline O corpo ele é um todo. & & $\mathrm{X}$ & $\mathrm{X}$ & $\mathrm{X}$ & $\mathrm{X}$ & $\mathrm{X}$ & $\mathrm{X}$ & $\mathrm{X}$ & 7 \\
\hline
\end{tabular}

Fonte: Elaboração própria (2017).

Para sete professoras, "O corpo ele é um todo". A compreensão apontada busca olhar o corpo para além das estruturas biológicas, indicando que as ações humanas dependem das condições em que ele é desenvolvido. O corpo necessita estar bem consigo para relacionar-se com o outro:

[...] então, se o corpo não tiver em bom funcionamento, claro que nada vai dar certo [...]; para poder você desenvolver um bom trabalho, o corpo tem que tá em boas ações. (VIOLETA).

[...] conjunto de órgãos que funcionam em sintonia um com o outro, e cada um deles tem uma função diferenciada, mas que é necessário que todos estejam em sintonia para que funcionem bem. (MARIA).

Essa totalidade evidenciada na visão dos sujeitos reflete-se na concepção de totalidade humana defendida por Morin (2011), para o qual o ser humano não é só uma tessitura biológica, tampouco um ser cultural, mas o entrelaçamento dessas duas dimensões. Há no ser humano uma complexidade existencial que the garante a 
possibilidade de múltiplas vivências. No caso da Educação do Campo, as vivências estão relacionadas principalmente com os espaços naturais e com o modo de vida das famílias.

Seguindo a análise do quadro, cinco entrevistadas afirmaram que o corpo "Ele está presente em todos os momentos". Assim assegurou Ervas das Rosas: "O dia todo $O$ seu corpo ele serve para tudo, para você andar, para você fazer o seu movimento, para você pensar. Ele tem dias que ele está triste, tem dia que ele está alegre [...]". No entendimento de Gonçalves (2012, p. 102), “[...] nós somos presença por intermédio do corpo - o corpo é presença, que ao mesmo tempo, esconde e revela nossa maneira de ser-no-mundo". Como corpo, o homem existe, pois "[...] as mentes não habitam cadáveres" (FREIRE, 1991, p. 26).

"O corpo é tudo em nossa vida", assim expressaram quatro professoras. As entrevistadas procuraram evidenciar que o corpo é a forma principal de locomoção, de socialização e de produção, como bem se observa na fala da professora Helen. O corpo é um conjunto de partes que são responsáveis pelas ações do indivíduo, como pensar e movimentar. "[...] o nosso corpo ele tem que estar preparado [...]; as nossas partes elas têm que estar preparadas para enfrentar o dia a dia na nossa forma de pensar, de agir, movimentar, para poder desenvolver esse trabalho dentro do nosso local de trabalho" (HELEN).

Para outra professora, "O corpo é tudo aquilo que tem massa e ocupa lugar no espaço". Essa afirmativa foi da professora Bem-te-vi. Seus argumentos dizem respeito à existência do corpo como sendo algo visível, palpável e responsável pela comunicação com outrem.

[...] tudo que está ao nosso redor é um corpo [...]; nós somos seres que estamos sempre no espaço físico [...]; nós somos um corpo, em pessoa, então perante nossos alunos nós somos; eles veem a gente assim como um espaço, no caso físico, estão vendo a gente se comunicar com eles através dos gestos, através dos movimentos, então tudo isso acredito que tem no espaço físico ao nosso redor. (BEM-TE-VI).

Em contraposição, uma professora referiu-se ao corpo como "Uma máquina". Assim enfatizou a professora Mary:

[...] uma máquina, quando ela dá um problema em uma peça, aí descontrola tudo; a gente não vai fazer algo nem chegar pelo menos ao nosso trabalho; e uma pessoa não pode fazer algo [...] sem saúde. Assim

Educação \& Formação, Fortaleza, v. 5, n. 13, p. 113-131, jan./abr. 2020

DOI: https://doi.org/10.25053/redufor.v5i13.1439

http://seer.uece.br/redufor 
do nosso corpo [...] tipo uma máquina que funcione, porque, se uma peça quebrar ou a gente, fica tudo descontrolado, assim sem poder fazer nada.

O corpo-máquina induz à ideia de corpo-objeto, ligado à visão cartesiana que o fragmenta, transformando-o em corpo oprimido e alienado, incapaz de pensar por si. Para Foucault (2014, p. 135), o corpo é tratado como uma máquina que segue os comandos e sua presença é útil apenas para o sistema de produção: "[...] o corpo humano entra numa maquinaria de poder que o esquadrinha, o desarticula e o recompõe".

O entendimento de corpo-máquina foi superado pela Educação do Campo, pois "[...] a visão de campo da Educação do Campo exige por si só uma visão mais alargada de educação das pessoas, à medida que pensa a lógica da vida no campo como totalidade em suas múltiplas e diversas dimensões" (CALDART, 2008, p. 78). De modo geral, para a maioria das entrevistadas, o corpo é a possibilidade de existência do indivíduo.

Após as respostas da primeira pergunta, foi realizada a segunda indagação:

Quadro 2 - Unidade de significado referente à questão: Que sentidos você atribui ao corpo na sua prática docente?

\begin{tabular}{|c|c|c|c|c|c|c|c|c|c|}
\hline Sujeitos & & & & & & & & & \\
\hline Unidades de significado & 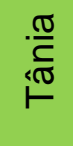 & $\begin{array}{l}\frac{\pi}{5} \\
\frac{\pi}{\pi} \\
0\end{array}$ & $\begin{array}{l}\frac{\vec{N}}{2} \\
\frac{\tilde{N}}{2}\end{array}$ & 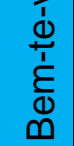 & $\begin{array}{l}\frac{\widetilde{\Phi}}{\Phi} \\
\frac{\Phi}{I}\end{array}$ & 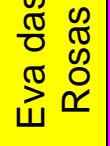 & $\frac{\frac{\pi}{0}}{\frac{\mathrm{J}}{\mathrm{O}}}$ & $\begin{array}{l}\frac{\pi}{\frac{\pi}{\pi}} \\
\sum\end{array}$ & 嵒 \\
\hline Transmissor e receptor de conhecimento. & & $x$ & & & & & & & 1 \\
\hline $\begin{array}{l}\text { Meio para contribuir para o conhecimento das } \\
\text { crianças. }\end{array}$ & & & $\mathrm{x}$ & & $\mathrm{x}$ & $\mathrm{x}$ & $\mathrm{x}$ & $\mathrm{X}$ & 5 \\
\hline Relação é de diálogo e respeito. & $\mathrm{x}$ & & $\mathrm{x}$ & & & & $\mathrm{x}$ & $\mathrm{x}$ & 4 \\
\hline $\begin{array}{l}\text { O corpo do aluno é movimento, gestos, é o } \\
\text { comportamento deles. }\end{array}$ & $\mathrm{X}$ & & & $\mathrm{x}$ & $\mathrm{x}$ & $\mathrm{X}$ & $\mathrm{x}$ & & 5 \\
\hline Ele está voltado para leitura. & & $x$ & & $x$ & $x$ & & & $\mathrm{x}$ & 4 \\
\hline Relação família, escola, professor e criança. & & & $\mathrm{X}$ & & & $\mathrm{x}$ & & $\mathrm{x}$ & 3 \\
\hline $\begin{array}{l}\text { Não existe um modelo de aluno, cada pessoa é } \\
\text { uma pessoa. }\end{array}$ & & & & $x$ & & $\mathrm{X}$ & & $x$ & 3 \\
\hline $\begin{array}{l}\text { Sinta-se (aluno) bem na escola também, que } \\
\text { ele tenha vontade de aprender. }\end{array}$ & $\mathrm{x}$ & & & & & $\mathrm{x}$ & $\mathrm{x}$ & $\mathrm{x}$ & 4 \\
\hline
\end{tabular}

Fonte: Elaboração própria (2017).

No Quadro 2, nota-se que o sentido do corpo do aluno para a maioria das professoras é "Meio para contribuir para o conhecimento das crianças"; cinco das professoras comungam dessa visão. As educadoras demonstraram intencionalidade em 
contribuir com o desenvolvimento dos discentes para além da sala de aula, enxergando-os como atores sociais capazes de constituir suas próprias histórias e superando os conflitos sociais em que eles estão imersos.

Assim, as professoras buscavam fazer da escola um instrumento de transformação social, por meio da formação do cidadão crítico. Essa afirmativa é notória na fala da professora Mary, que iniciou sua resposta comparando o corpo a uma máquina, no entanto, da maneira colocada por ela, o trato que realiza com o educando é tarefa improvável para uma máquina:

Eu acho que seja como uma máquina para amparar muitas coisas, muitas pessoas, muitos seres, que eu possa também colocar essas peças, essas crianças junto a mim, e poder ajudar, contribuir para o conhecimento dessas crianças, desses seres que eu estou trabalhando, o ser humano. E, formando uma criança, que é todo o objetivo de um profissional, de um professor que trabalha com crianças, o objetivo é a gente chegar com uma criança sabendo se expressar, sabendo se comunicar em qualquer lugar que ela chegue [...]; nós estamos envolvidas num projeto que eu faço parte [...]; agora no pagamento que saiu, eu fui lá comprar brinquedos, que é para mim trazer, que todo ano eu compro sempre brinquedos; este ano infelizmente não vai dar para eu dar para todos.

A professora Mary citou a preocupação em propiciar às crianças novas vivências por meio de brincadeiras. O projeto relatado por ela refere-se ao Dia das Crianças. Ela lamentou então que o recurso financeiro disponível era insuficiente para adquirir brinquedos para todos, pois sabia o quanto as crianças esperavam ganhá-los, entretanto, preocupada em não os deixar tristes, ela Ihes prometia um abraço; talvez mais significativo do que o próprio brinquedo. Nesse caso, a criança do campo sofre com a escassez financeira, o que inviabiliza a compra de brinquedos.

Para as professoras Helen e Violeta, o trabalho docente, apesar de ser desafiador, é primordial que seja empreendido segundo os alunos, a partir da necessidade de ser criança deles, de brincar, de movimentar-se e terem segurança. Nesse aspecto, para Violeta, a expressividade do corpo é importante no exercício da prática docente, sendo por meio dele que ela se comunica com os estudantes, e esse processo de comunicação é pertinente na definição das metodologias de aprendizagem. Fernandes, Cerioli e Caldart (2011, p. 54) afirmam:

[...] compromisso ético/moral com cada e de cada participante de nossas práticas educacionais, enquanto pessoas humanas, singulares sociais,

Educação \& Formação, Fortaleza, v. 5, n. 13, p. 113-131, jan./abr. 2020

DOI: https://doi.org/10.25053/redufor.v5i13.1439

http://seer.uece.br/redufor 
que têm necessidades, interesses, desejos, saberes, cultura, e que merecem respeito, disponibilidade e seriedade de educadores/educadoras, de entidades, de governos. Este compromisso tem como uma de suas implicações o esforço que devemos fazer para traduzir em políticas públicas, em relações pedagógicas e em metodologias de aprendizagem, os demais compromissos.

A relevância de ser educador constitui-se na sua contribuição para a formação humana, preparando para o enfrentamento dos desafios sociais, políticos e culturais que permeiam a realidade da sociedade. Para Gerone Junior e Hage (2013), ser professor ribeirinho ultrapassa os limites da sala de aula, desempenhando funções que, em tese, não fazem parte das exigências acadêmicas de um educador.

Para cinco professoras, "O corpo do aluno é movimento, gestos, é o comportamento deles". Para elas, o corpo é a primeira forma de contato e, portanto, a primeira forma de comunicação com os estudantes. É nele que está expressa a intencionalidade dos movimentos.

O corpo do aluno na sala de aula tem muito sentido, o movimento dele, os gestos como eles agem na sala de aula, o comportamento deles, no momento que a gente está se expressando para eles, no momento de estar chamando a atenção deles. Como eu sei, essa turma são alunos agitados, então eles estão sempre em movimento, eles não quietam só num lugar; estão fazendo sempre um movimento físico, não são alunos que estão quietos só naquele lugar, eles ocupam o espaço deles, no momento deles [...]. O aluno quietinho não quer dizer que ele está aprendendo, ele está quietinho, mas ele não tá entendo nada. Então, eles expressam a maneira, o modo deles que eles estão lá na sala, mas, mesmo assim, eles aprendem alguma coisa. (BEM-TE-VI).

No discurso da professora Bem-te-vi, salientam-se elementos que originariam novos estudos. A fala em questão constitui-se em olhar o aluno nas mais diversas peculiaridades: o corpo complexo, comunicável, inteligível, corpo-criança. É a pura materialidade do "Eu sou corpo". Ela reconhece o desenvolvimento dos educandos, ainda que eles não estejam focalizados na leitura e escrita. Essa professora estava trabalhando com uma turma de discentes que fazia parte do programa "Se Liga", idealização do Instituto Ayrton Senna (on-line): "[...] se destina a estudantes não alfabetizados e em estado de defasagem idade-série matriculados no $3^{\circ}$ ao $5^{\circ}$ ano do ensino fundamental. [...] promove a alfabetização plena desses alunos [...]".

As entrevistadas afirmaram ainda que o movimento é necessário no desenvolvimento das suas aulas, por diversificar as atividades para torná-las mais

Educação \& Formação, Fortaleza, v. 5, n. 13, p. 113-131, jan./abr. 2020

DOI: https://doi.org/10.25053/redufor.v5i13.1439

http://seer.uece.br/redufor 
dinâmicas e mais prazerosas para o aluno. Reconheceram que a infância se funda por diferentes aspectos, por isso havia momentos em que proporcionavam liberdade aos discentes, quando afirmaram que os deixavam à vontade. Cabe salientar que esse momento de maior liberdade não deixava de ser acompanhado pelas docentes, pois concebiam que a criança precisa de limites, ou seja, mesmo os estudantes fazendo suas próprias escolhas, o olhar do educador é atento e importante. Para Freire (2016, p. 70), "[...] professor e alunos juntos podemos aprender, ensinar, inquietar-nos, produzir juntos e juntos igualmente resistir aos obstáculos à nossa alegria". No olhar dos referidos professores, o educando precisa do direcionamento do educador. Nesse sentido, há convicção de que o aprendiz é consequência do trabalho desenvolvido pelo docente.

O corpo, na compreensão da maioria dos professores, constitui a possibilidade de interação com o outro, por meio dele se faz a primeira comunicação com os alunos, além disso, é através do corpo que se desenvolvem as atividades voltadas para o ensino-aprendizagem. Os entrevistados conhecem as peculiaridades dos seus discentes, assim os gestos corporais emitidos por eles permitem aos docentes diferenciá-los, fazendo com que as mudanças ocorridas no cotidiano dessas crianças sejam perceptíveis ao olhar dos professores, pois em cada gesto há um ou vários sentidos transparecidos e interpretados.

Para Merleau-Ponty (2011, p. 251), o "[...] sentido dos gestos não é dado, mas compreendido, quer dizer, retomado por um ato do espectador". Com isso, obtém-se "[...] a comunicação ou a compreensão dos gestos pela reciprocidade entre minhas intenções e os gestos do outro, entre meus gestos e intenções legíveis na conduta do outro" (MERLEAU-PONTY, 2011, p. 251). Sobre esse aspecto, Nóbrega (2010, p. 36) assevera:

Uma teoria da corporeidade deve estar atenta para a multiplicidade de sentidos dos saberes sobre o corpo, buscando não reduzir o fenômeno a categorias simplificadoras, mas permitir diferentes olhares, diferentes aproximações e abordagens primando pelo diálogo, pela comunicação entre os elementos que configuram esse universo multifacetado.

A respeito da comunicação e os sentidos que emergem da expressão corporal, Merleau-Ponty (2011, p. 253) destaca: "[...] É por meu corpo que compreendo o outro, assim como é por meu corpo que percebo as coisas". No contexto das escolas ribeirinhas, Gerone Junior e Hage (2013) constatam que a realidade é muito difícil, pois a concretização do ensino-aprendizagem requer, entre caminhadas e remadas até a 
escola, a superação de muitos desafios, como problemas com drogas, crimes e ausência da família.

Outro sentido atribuído ao corpo para quatro professoras foi o de "Relação de diálogo e respeito". A professora Mary citou o exemplo de dois alunos que haviam migrado de outro estado. Tais estudantes chamavam a atenção de outros professores pela forma que se comportavam em sala de aula; além disso, a mãe das crianças lhe havia alertado que teria muito trabalho com os filhos. Com isso, a professora usou a estratégia do diálogo, afirmando que a criança que vive nos centros urbanos possui vivências diferentes daquelas crianças que residem no campo, onde há vasta possibilidade de brincadeiras explorando o ambiente natural.

Além desses aspectos, constatou-se, inclusive, que as professoras têm buscado inserir as crianças em processo de formação crítica, aprendendo a respeitar o próximo e a si mesmas. A escola é um local onde se buscam outras possibilidades de vida, ampliar conhecimento, interagir com outras pessoas. Para Gerone Junior e Hage (2013), a escola pode ser um lugar alegre, dinâmico e, na mesma proporção, também sério e competente, uma qualidade não anula a outra, porque, quando se fala em escola, refere-se à educação, docência, ensino e aprendizagem.

As professoras que apostaram no diálogo e no respeito demonstraram compreender a importância da infância. A criança não precisa ser um "pequeno adulto" para ter verdade em sua vivência, pois sua fala, seus pensamentos e suas ações são repletas de sentidos e significados. Nesse caso, como argumentam Gerone Junior e Hage (2013, p. 31), "[...] o professor, então, passa a ser o sujeito que cuida e olha para o educando, estabelecendo com ele uma relação de afetividade e compromisso". A prática do professor é permeada pelo compromisso com o desenvolvimento da criança.

Outra unidade de relevância foi esta: "Sinta-se (aluno) bem na escola também, que ele tenha vontade de aprender". Quatro professoras tiveram essa compreensão. Eram várias as estratégias por elas experimentadas no sentido de tornar a escola e a sala de aula um espaço de aprendizagem, de interação social, de respeito e de parceria.

Nossos desafios são situações adversas que a gente encontra na sala de aula, em que sempre a gente está tentando conseguir fazer algo para que o aluno consiga aprender [...]; o nosso objetivo é esse: que ele saia não como ele chegou, nem pior, que ele saia melhor do que ele chegou, que ele sinta-se bem na escola, que ele tenha vontade de aprender [...], a 
gostar da escola, ficar mais tempo, querer tá na escola, então a gente vai sentindo, assim, que já houve uma mudança do comportamento. (MARIA).

Para quatro professoras, o corpo em sala de aula "Ele está voltado para leitura". Conforme identificou Maria: "[...] começou também a aprender as coisas que ainda não sabia, exemplo: não sabia ler nem escrever bem [...]'. Contudo, os espaços para realização dessa atividade, segundo dados, demonstram que: "79,1\% dos matriculados em escolas urbanas têm acesso à biblioteca ou sala de leitura. A situação dos matriculados da zona rural é diferente, $35,4 \%$ deles têm acesso a esses espaços na escola em que estudam" (INEP, 2017, p. 14). Observa-se que nas escolas rurais há defasagem de locais apropriados para a realização da leitura.

Nesse contexto, torna-se desafiador o exercício da prática docente, por isso as professoras, três delas especificamente, ao atribuírem sentido ao corpo, suscitaram duas unidades de significado de convergência: "Relação família, escola, professor e criança"; "Não existe um modelo de aluno, cada pessoa é uma pessoa".

Segundo as entrevistadas, a relação entre família e escola caracteriza-se como uma parceria que exerce influência no processo de ensino-aprendizagem e, portanto, no desenvolvimento do aluno; sem ela, os desafios da prática docente são ainda maiores. Essa relação, ainda que não seja o foco de análise da pesquisa, traz consigo elementos que surgiram no discurso das professoras, por isso é pertinente apontá-los: na unidade "Não existe um modelo de aluno, cada pessoa é uma pessoa", refere-se à complexidade que se tem em trabalhar com diversos tipos de comportamentos e com as realidades diferenciadas. Assim, as professoras buscavam idealizar ações que pudessem atender às necessidades dos alunos, buscando envolvê-los em ações planejadas:

[...] não existe um modelo de aluno, cada pessoa é uma pessoa e tem um comportamento diferente, necessidades diferentes, dificuldades, porque, quando se fala de pessoa, todos nós temos limites, temos nossas limitações. (MARIA).

[...] nós temos vários modelos de aluno, principalmente através do comportamento [...]; tem que agradar as crianças de várias formas, temo modo de falar com aquela criança [...]; a gente faz algumas brincadeiras na sala de aula, chama eles para fazer um movimento [...]. Eu não sou professora de ficar com as crianças todo tempo sentada, sempre eles estão em movimento. (EVA DAS ROSAS).

Educação \& Formação, Fortaleza, v. 5, n. 13, p. 113-131, jan./abr. 2020

DOI: https://doi.org/10.25053/redufor.v5i13.1439

http://seer.uece.br/redufor 
Contrapondo-se à visão de corpo-sujeito, uma professora afirmou que o corpo é "Transmissor e receptor de conhecimento". É válido salientar que, no período da pesquisa, ela possuía apenas dois meses de experiência em sala de aula. Estava em um processo de reconhecer-se na docência, pois antes exercia atividades operacionais na escola quando iniciou o ensino superior. Em sua avaliação, a brincadeira não é algo positivo no desempenho do aluno, pois o ideal é aquele que se concentra nas tarefas conteudistas. Para Freire (2016, p. 25), “[...] ensinar não é transferir conhecimento, conteúdos, nem formar é ação pela qual um sujeito criador dá forma, estilo ou alma a um corpo indeciso ou acomodado".

Salienta-se que a maioria dos docentes percebia que seu papel em sala de aula suplantava as questões burocráticas. Em relação aos educandos, buscavam formá-los como seres capazes de mudança, principalmente por todos os percalços políticos, econômicos e sociais que insistem em fazer do ambiente rural um lugar de retrocesso.

\section{CONSIDERAÇÕES FINAIS}

A pesquisa propôs investigar, a partir dos fundamentos da Corporeidade e da Educação do Campo, os sentidos que os professores atribuem ao corpo na prática docente nos territórios rurais de Santarém, na Amazônia paraense. O grande desafio do estudo foi traçar um diálogo entre a Corporeidade, territórios e Educação do Campo sem fazer aquilo que ela mais questiona - a fragmentação.

Ao fazer a relação da abordagem da Corporeidade com a Educação do Campo, constataram-se os arrolamentos que ambas estabelecem. Na Corporeidade, negam-se a opressão do sujeito, a docilização e o silenciamento do corpo. Já na Educação do Campo, não apenas como termo que ultrapassa o entendimento de Educação Rural, demonstra-se a superação da opressão dos camponeses ao longo de décadas. Por isso, pensar a Educação do Campo reflete a organização social de sujeitos que buscam, por meio da vivência da corporeidade, formas de superação das condições opressoras com as quais foram historicamente tratados.

Portanto, ao investigar os sentidos atribuídos ao corpo pelas professoras na prática docente no território rural de Santarém, constatou-se que os sentidos atribuídos por elas denotam a preocupação com a formação integral das crianças, por isso, em 
diversos momentos de suas falas, surgiram questões como a família, as dificuldades financeiras, o investimento na brincadeira, entre outras, que não foram objeto de análise, mas que, segundo elas, influenciam no exercício da docência e consequentemente no processo de aprendizagem. Assim, para elas, o corpo é uma totalidade; sem o corpo, não há presença humana, porque ele precisa estar presente em todos os momentos da ação do sujeito. Sem ele, nenhuma outra atividade se realiza.

Nos sentidos atribuídos pelas docentes ao corpo, ficou evidente a relação estabelecida com os alunos, na qual os movimentos e os gestos definiam 0 comportamento de cada educando. Para a maioria das professoras, discente quietinho na sala de aula não é sinônimo de aprendizagem. Assim, há momentos em que o estudante interage mais por meio do movimento, apresentando uma aprendizagem mais significativa. Desse modo, a aquisição de conhecimentos ganha mais sentido quando as especificidades locais - no caso deste estudo, a modalidade ribeirinha - fazem parte do contexto do ensino-aprendizagem.

Considerando que o corpo é a materialidade da existência, verificou-se que, na prática docente das professoras ribeirinhas, ele é meio de comunicação com as crianças; por meio dele, são produzidas e reproduzidas as manifestações culturais, os problemas sociais; a aprendizagem ocorre pelo corpo. Assim, a indagação sobre os sentidos atribuídos ao corpo na sala de aula pode não ter gerado espanto para as docentes, com exceção da professora com menos tempo de experiência, porque a maioria das professoras enxergou com naturalidade a relação do corpo com o processo de ensinar e aprender.

Verificou-se que, apesar de as questões "corpo" e "Corporeidade" não serem uma discussão que faça parte do cotidiano dos professores e talvez não tenham sido trabalhadas em suas formações acadêmicas, ainda assim, os argumentos revelados nos depoimentos confirmaram a presença da Corporeidade nas práticas docentes.

\section{REFERÊNCIAS}

CALDART, R. S. Sobre Educação do Campo. In: SANTOS, C. A. (Org.). Educação do Campo: campo-políticas públicas-educação. Brasília, DF: Incra: MDA. 2008. p. 67-86. 
COUTO, H. R. F. A criança e as manifestações lúdicas de rua e suas relações com a educação física escolar. Piracicaba, 2008. 131 f. Dissertação (Mestrado em Educação Física) - Programa de Pós-Graduação em Educação Física, Universidade Metodista de Piracicaba, Piracicaba, 2008.

FERNANDES, B.; CERIOLI, P. R.; CALDART, R. S. Primeira Conferência Nacional "Por Uma Educação Básica do Campo". In: ARROYO, M. G.; CALDART, R. S.; MOLINA, M. C. (Org.). Por uma educação do campo. 5. ed. Petrópolis: Vozes, 2011. p. 19-62.

FOUCAULT, M. Vigiar e punir: nascimento da prisão. Petrópolis: Vozes, 2014.

FREIRE, J. B. De corpo e alma: o discurso da motricidade. São Paulo: Summus, 1991.

FREIRE, P. Pedagogia da autonomia: saberes necessários à prática educativa. 54. ed. Rio de Janeiro: Paz e Terra, 2016.

GERONE JUNIOR, A.; HAGE, S. A. M. Ser professor ribeirinho: os desafios que emergem da educação e da ação pedagógiça em escolas ribeirinhas da Amazônia. In: ABREU, W. F.; OLIVEIRA, D. B.; SILVA, É. S. (Org.). Educação ribeirinha: saberes, vivencias e formação no campo. 2. ed. Belém: UFPA, 2013. p. 19-41.

GONÇALVES, M. A. S. Sentir, pensar, agir: corporeidade e educação. 15. ed. Campinas: Papirus, 2012.

INEP - Instituto Nacional de Estudos e Pesquisas Educacionais Anísio Teixeira. Censo escolar da educação básica 2016: notas estatísticas. Brasília-DF: Inep, 2017.

INSTITUTO AYRTON SENNA. Programa Se Liga. 2018. Disponível em: http://www.institutoayrtonsenna.org.br/pt-br/instituto.html. Acesso em: 10 jan. 2018.

MERLEAU-PONTY, M. Fenomenologia da percepção. 4. ed. São Paulo: Martins Fontes, 2011.

MINAYO, M. Pesquisa social: teoria, método e criatividade. Petrópolis: Vozes, 1994.

MORIN, E. Os sete saberes necessários à educação do futuro. São Paulo: Cortez; Brasília, DF: Unesco, 2011.

MOREIRA, W. W. Do corpo à corporeidade na educação formal: mudança paradigmática. In: FABRIN, F. C. S.; NÓBREGA, M. L. S.; TODARO, M. Á. (Org.). Corpo e educação: desafios e possibilidades. Jundiaí: Paco, 2014. p. 149-166.

MOREIRA, W. W.; SIMÕES, R.; PORTO, E. Análise de conteúdo: técnica de elaboração e análise de unidades de significado. Revista Brasileira de Ciência e Movimento, Taguatinga, v. 13, n. 4, p. 107-114, 2005.

NÓBREGA, T. P. Corporeidade e Educação Física: do corpo-objeto ao corpo-sujeito. 2. ed. Natal: UFRN, 2005. 
RIBEIRO, M. Educação Rural. In: CALDART, R. S. et al. (Org.). Dicionário da Educação do Campo. Rio de Janeiro: Escola Politécnica de Saúde Joaquim Venâncio; São Paulo: Expressão Popular, 2012.

SIANI, S. R.; CORREA, D. A.; CASAS, A. L. Fenomenologia, método fenomenológico e pesquisa empírica: 0 instigante universo da construção de conhecimento esquadrinhada na experiência de vida. Revista de Administração da Unimep, Piracicaba, v. 14, n. 1, p. 116-219, 2016.

\section{Rosenilma Branco Rodrigues (Brasil, Pará, Santarém) \\ Universidade Federal do Oeste do Pará (Ufopa)}

Mestra em Educação pela Universidade Federal do Oeste do Pará (Ufopa), licenciada em Filosofia pela Faculdade Pan-Americana (FPA) e graduada em Turismo pelo Instituto Esperança de Ensino Superior (lespes), com curso de aperfeiçoamento "A escola e a cidade: políticas públicas educacionais" pela Ufopa. Foi professora de Filosofia e Sociologia da Secretaria Estadual de Educação do Pará. É integrante do Grupo de Pesquisa Cognições e Práticas Formativas Educacionais em Espaços Escolares e Não Escolares - Ufopa.

Lattes: http://lattes.cnpq.br/6154283230706443.

E-mail: rosebrancor@yahoo.com.br.

\section{Hergos Ritor Fróes de Couto (Brasil, Pará, Santarém)} Universidade Federal do Oeste do Pará (Ufopa)

Pós-doutor em Desporto pela Faculdade de Desporto da Universidade do Porto, Portugal, desenvolvendo pesquisa na temática que envolve a conciliação da formação desportiva com a formação escolar de jovens jogadores de futebol das categorias de base do Futebol Clube do Porto, doutor em Educação pela Universidade Nove de Julho (Uninove), mestre em Educação Física pela Universidade Metodista de Piracicaba (Unimep), graduado em Pedagogia pela Uninove, licenciado e bacharel em Educação Física pela Uninove e bacharel em Administração de Empresas pelas Faculdades Integradas Sant'Anna e São Paulo. Professor efetivo da Universidade Federal do Oeste do Pará (Ufopa), na categoria adjunto IV. Atua principalmente nos campos de Educação e Corporeidade e Educação e Esporte.

Lattes: http://lattes.cnpq.br/4185846607001228.

E-mail: hergos@hotmail.com.

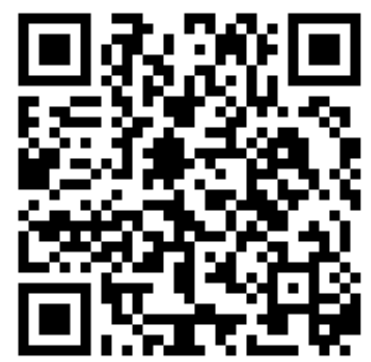

Recebido em 07 de julho de 2019.

Aceito em 23 de setembro de 2019. 